\title{
Factitious disorders in children: clinical and therapeutic considerations
}

\author{
M. Jafferany', A. Kobusiewicz ${ }^{2}$, B.R. Ferreira ${ }^{3}$, S. Garan ${ }^{4}$, O. Havryliuk ${ }^{5,6}$ \\ ${ }^{1}$ Central Michigan University College of Medicine, Saginaw, MI, USA \\ 2 University of Lodz, Lodz, Poland \\ ${ }^{3}$ University of Coimbra, Coimbra, Portugal \\ ${ }^{4}$ Estebel Aesthetic Clinic, Istanbul, Turkey \\ ${ }^{5}$ Kharkiv National Medical University, Kharkiv, Ukraine \\ ${ }^{6}$ State Establishment «Institute of Dermatology and Venereology of NAMS of Ukraine», Kharkiv, Ukraine
}

\begin{abstract}
There is considerable lack of awareness about child and adolescent population intentionally producing dermatological symptoms and this unique group has remained underreported.

The objective: This review focuses on educating dermatologists about the pathogenesis, symptomatology and management options of factitious disorders.

Materials and methods: Medline search was conducted for last two decades and articles containing words factitious disorders and dermatitis artefacta were identified.

Results: Children with factitious disorders suffer from other psychiatric disorders, particularly depression and borderline personality traits. The prevalence ranges from $0.5-2 \%$. Majority of children and adolescents who engage in self-injurious behaviors do not intend to commit suicide, instead they use their self-injurious behavior as an appeal for help or a non-verbal form of communication. Conclusions: Patients should not be confronted to explore the underlying psychological conflicts, rather gentle, non-judgmental and empathic approach be utilized for a good therapeutic rapport. High index of suspicion on provider's part is a key to diagnosis. Along with dermatological care, psychopharmacological interventions and psychotherapeutic techniques have proven helpful in this population. Key words: psychocutaneous disorders, factitious disorders, psychodermatology.
\end{abstract}

DOI: 10.33743/2308-1066-2019-2-8-15

\section{Introduction}

Factitious disorders (FD) are relatively rare primary psychiatric disorders with somatic expression. It is a subgroup of diversified self-inflicted lesions where the patient denies having caused an injury. Severe psychological distress and desire to play a role of a sick person without clear external incentives are supposed to be motivating factors of inflicting self-harm [1]. Patients with FD are highly imaginative and demonstrate extensive knowledge on medical specialties while fabricating symptoms [2-4]. A study conducted on $455 \mathrm{FD}$ patients revealed that such patients are usually affected by endocrinological, cardiological and dermatological problems [5]. Dermatology is particularly concerned with FD as the skin is easily accessible to inflict self-harm and injuries are highly visible.

According to literature, FD is also known as Munchausen syndrome, hospital hooper syndrome, doctor or hospital shopping, pseudologia phantastica, phatomimia [6], selfharm [7], auto-destructive syndrome [8], self-mutilation [9], dermatitis artefacta [10] and factitious dermatitis. The last two names wrongly imply inflammation. These terms may be confusing for health care specialists and might pose difficulties in conducting systematic studies on epidemiological data, development, pathogenesis and treatment of the disease. One third of physicians treating patients with dermatological FD complain that they are insufficiently informed on ways of setting a diagnosis [11]. A clear classification and uniform terminology was introduced by the European Society for Dermatology and Psychiatry (ESDaP) group in 2013, which to some extent made the issue of self-inflicted lesions more clear [12].

Although the clear classification was made, it may still be difficult to establish a proper diagnosis since the disease has different clinical manifestations and dermatologists demonstrate limited knowledge of underlying psychological background. The prevalence of psychiatric comorbidity in outpatient dermatological settings is estimated to be $30 \%$ [13]. A review of 18 studies on a cohort of 52,000 patients showed that the prevalence of self-inflicted skin lesions ranged from $0.03 \%$ to $9.4 \%$ with weighted mean $0.9 \%$ [9]. 
Epidemiological data suggest that self-inflicted skin lesions are more common than it was previously thought [14]. Although FD symptoms have psychiatric component, many patients are first presented to dermatologists. Most providers will encounter at least one patient with FD in all their clinical practice [5]. These results clearly imply that dermatologists should get familiar with psychiatric issues, making brief psychological evaluation and involving in cooperation with mental health professionals so as to be able to effectively refer such patients to them. Yet, Jafferany et al. noted that only $18 \%$ of dermatologists confirmed that have a clear understanding of psychodermatology and only $42 \%$ could clearly identify and treat psychocutaneous disorders [15].

A review of literature on factitious disorders, reveal that not only adults simulate medical conditions. Also, a number of children and adolescents were reported to demonstrate FD imposed on self [16]. In pediatric literature, much attention has been paid to Munchausen syndrome by proxy (MSBP) in which children are victims of intentional harm or feigning, done by their caregivers who try to fulfill their own psychological needs. This condition is a severe form of child abuse [17]. According to DSM-V diagnostic criteria, the perpetrator, not the victim, is diagnosed with factitious disorder imposed on another (eponym Munchausen syndrome by proxy). This review presents only FD imposed on self in children since a full review of FD imposed on another has been previously conducted elsewhere [18].

Children with FD are mostly seen as problematic or «disarming» patients with regards to management of the disease. To make the treatment effective, a dermatologist is required to become aware of psychological background, leading to falsifying skin lesions, which in turn, is a cause of severe psychological suffering. It is suggested that by inflicting self-harm, children merely cry for help [19]. An immediate referral to a mental health professional, without establishing a trustful patient-doctor relationship, mostly results in a therapeutic failure since the patient is not aware of his/her psychological motivations for such a behavior. Besides, a mental illness is usually a stigma and evokes embarrassment, which makes the patient feel rejected by his/her dermatologist [20]. If the patient is able to accept psychological treatment, the prognosis is usually positive.

The aim of this paper is to provide dermatologist with extensive knowledge about FD in children, their psychological background and methods of management which should be conducted in collaboration with mental health professionals. The role of dermatologists is essential in management of patients affected by both dermatological and mental disorders.

\section{Definitions}

FD are classified in the DSM-5 as somatic symptom and related disorders. This expression refers to artificial or fake, self-provoked diseases without clear external incentives, in many medical specialties. The following examples of FD imposed on self in children were reported: manipulation of thermometer to simulate high fever of unknown origin, manipulation of insulin to simulate ketoacidosis or hypoglycemia, urine tampering to falsify hematuria and more [5]. FD in dermatology is a subgroup of diversified self-inflicted skin lesions. Here patient induces skin lesions. $\mathrm{He} /$ she denies causing any skin lesions or keeps his/her selfharm secret without demonstrating any obvious incentives for self-inflicting behavior. This description differentiates FD from malingering, skin picking and self-inflicted skin lesions, caused by other obsessive and compulsive behaviors.

The ESDaP group proposed a terminology and classification of self-inflicted skin lesions that includes several types of self-harm to the skin and defined four main categories [12]:

1) Non-hidden and non-denied underlying behavior with compulsive spectrum: skin picking and skin-related damaging symptoms.

2) Non-hidden and non-denied underlying behavior with impulsive spectrum: skin picking and skin-related damaging symptoms.

3) Hidden or denied underlying behavior with no external incentives: FD in dermatology.

4) Hidden or denied behavior with external incentives: malingering in dermatology.

This classification is based on the answers to the questions that may help health care professionals to establish a diagnosis: «Is the behavior responsible for somatic damage, denied or kept secret by the patient?» If the answer to this question is positive, the next question differentiates between malingering and FD: «Are there any external incentives?»

ESDaP group differentiates two clinical subtypes of FD: Pathomimicry and Munchausen syndrome. Pathomimicry is defined as induction of lesions that mimic symptoms of diagnosed dermatological disorder [6] for example, Alopecia Areata-like lesions, caused by shaving hair that leads to an occurrence of patches. Patients with Munchausen syndrome complain about acute symptoms. They dramatically present their complaints and give false information on their medical history, by claiming that they had been hospitalized many times and administered many medical procedures [22]. Medical professionals might also do such patients even more harm when they are constantly asked to perform medical procedures by the patients for example skin biopsy. This eponym was coined by Asher in 1951 and referred to the Baron von Munchausen, Karl Friedrich Hieronymus, who was famous for telling fantastic and exaggerated stories from his journeys (pseudologia fantastica).

FD imposed on self shouldn't be mistaken for factitious disorders imposed on another (Munchausen syndrome by proxy), being a form of child abuse. A perpetrator, most often mother, induces illness in a child as she wants to play a role of a sick person. A caregiver for example invents symptoms by manipulating with blood and urine samples to prove that the child is really affected by a disease [22].

Harth et al [23] categorized FD into three groups:

1) Dermatitis artefacta syndrome (dissociated [nonconscious] self-injurious behavior. 
2) Dermatitis paraartefacta syndrome (disorders of poor impulse control, often as manipulation of an existing specific dermatoses [often semiconscious admitted self-injury].

3) Malingering (consciously simulated injuries and diseases to obtain maternal gain).

Classification of psychodermatological disorders and their nomenclature is still a subject of debate.

\section{Prevalence}

Precise epidemiology is difficult to establish due to diagnostic multifactorial challenges and the terminological complexity. Diagnostic uncertainties and lack of understanding of the disorder may lead to setting a wrong diagnose of the disorder. Most information on FD is based on case studies as prospective studies are difficult to conduct. Due to limitations in this field of study, it is impossible to obtain extensive knowledge, based on a large cohort.

The prevalence of FD in general hospitals varies between $0.6 \%$ and $3 \%$, thus in specialist clinics it may range between $0.02 \%$ and $0.9 \%$ [4, 24, 25]. Recent studies suggest the prevalence of FD in dermatology clinics is between $0.04 \%$ and $1.5 \%$. Females are mostly affected as the female/male ratio is as high as 20:1 and the majority of patients are about 20 years of age [10, $25,26]$. Studies evaluating FD in pediatric population reported that 1 out of 23,000 pediatric consultation reveals the occurrence of the disease [27, 28]. The mean age of children and adolescents has been found to be approximately 13 years and females prevail in these statistics [29].

\section{Pathogenesis}

It is important for dermatologists to better understand psychological factors of FD as in the future, they may be more able to feel empathic and be understanding to emotional suffering of the patient. Such an approach may help them avoid judging and effectively refer their patients to mental health specialist. This, in turn, will lead to therapeutic satisfaction.

FD is reported to be linked with psychological stressors. Most pediatric patients who inflict self-harm reveal quite a frequent history of stressful life events. They were frequently mentally or sexually abused or neglected in childhood [19, 30]. There are several case reports of self-inflicted skin lesions after serious bullying at school [28]. If the behavior is repetitive, it may suggest underlying emotional disturbances. Other authors have also described this emotional coping mechanism, of using skin as an organ to manifest patients' emotional distress [31]. It has been suggested that increased risk of developing self-harm in children is associated with comorbid psychiatric conditions and personality disorders [31]. Anxiety and depression were found to be the two most common psychiatric diagnoses in a FD pediatric population [27], whereas personality disorders in selfinflicted lesions, particularly borderline personality disorder, were widely described in professional literature
[32]. A systematic review of 455 FD cases [5] showed that the patients were more often affected by depression than personality disorders ( $41.8 \%$ versus $16.5 \%)$. Other common disorders that were identified in that review were substance abuse (15.3\%), anxiety (14.7\%), functional neurological symptoms (5.3\%) and eating disorders $(4.1 \%)$. Moreover, a total of $14.1 \%$ of patients demonstrated current suicidal ideation or a history of suicidal attempt. Another study observed that children, who had had a previous experience of victimization of illness falsification by their caregivers, also falsified illness by themselves [18, 33].

Professional literature does not clearly explain why children regulate their emotional imbalance, distress and social relationships by doing harm to them. Nock [34] in his review of self-injury proposed the following hypotheses:

a) a social learning hypothesis: behavior that was learned by observing others;

b) a self-punishment hypothesis: behavior to punish oneself for some wrongdoing or results from self-hate, self-deprecation, guilt or shame;

c) a social signaling hypothesis: a self-injury as a more effective way of communication or signaling distress than speaking or crying;

d) an implicit identification hypothesis: a self-injury as the most effective way of identification of coping strategy to regulate emotions;

e) a pain-analgesia or opiate hypothesis: in some patients with decreased pain sensitivity, a repeated selfinjury may increase levels of endorphins, which evokes a feeling of pleasure;

f) a pragmatic hypothesis: a self-injury as a fast and easy accessible method to cope with negative emotions;

g) a tension-regulation hypothesis: a self-injury as an immediate relief to unbearable tension.

The proposed hypotheses shed a light on the pathogenesis of self-inflicted lesions. However, further research on this topic should be conducted.

\section{Clinical Features}

Clinically, patients self-harm themselves without the direct intention of committing suicide. There are multiple mechanisms by which patient produce lesions including mechanical causes such as by pressure, friction, occlusion, biting, cutting, stabbing and mutilation. Some patients produce lesions by toxic damage such as using acids, alkalis and thermal causes. Other patients temper with their pre-existing infections or using various pharmacological agents such as insulin or heparin injections. The hallmark of dermatitis artefacta syndrome is unconscious self-injury and self-manipulation. The morphology of these lesions can imitate most skin diseases. Dermatitis artefacta syndrome must be suspected when a typical clinical pattern has atypical localization, morphology, histology or no response to standard treatment. In dermatitis paraartefacta, patients have impairment in impulse control, and they have lost control over their self-mutilation and they harm themselves obsessively. The examples 
of dermatitis paraartefacta are skin picking, acne excoriee, cheilitis factitia (lip licking dermatitis), onychophagia (nail biting), onychotillomania (nail picking), onychotemnomania (obsessively cutting nails), trichotillomania (hair pulling), trichotemnomania (compulsive shaving of hair), trichoteiromania (compulsive rubbing of hair) and trichodaganomania (compulsive biting of hair).

\section{Differential Diagnosis}

There are several conditions which could be included in the differential diagnosis of FD including psychotic disorders, affective disorders with psychotic components, autism spectrum disorder, emotionally unstable personality, child abuse, comorbidity with various organic diseases, plant dermatitis, cultural or religious practices, hypochondriacal delusions and various parasitosis.

\section{Psychological Aspects of FD}

It was previously theorized that patients with FD are aware of intentionally producing their illness, but they are uncertain of their motivation. Contrary to this previous concept of FD, it has recently been suggested that patients with FD are sometimes aware of why they choose to falsify a medical condition [35]. However, the psychology behind these motivations remains poorly understood.

FD is challenging to study because deceiving healthcare providers is one of the primary objectives of people with this condition. This patient group is often reluctant to participate in research studies and consequently, the psychology of FD is not well studied or understood. However, a few factors have been suggested. Among adult FD patients, psychological reasons underlying the condition include: the thrill of undergoing medical procedures [35]; a need for attention or care; a sense of control through the deception of healthcare providers [5]. The literature on the psychology of this condition within the pediatric population is particularly limited. However, a few theories have been proposed including disruption in childhood attachments and intergenerational transfer [36], which may help understand the psychology behind the production of these lesions.

\section{Disruption in Attachments}

Healthy relationships with caregivers are important for child development [2]. If there are problems in these relationships, children may seek to satisfy their innate need for caregiver attention by exhibiting illness behaviors. In this way, children can satisfy their need for comfort and protection through the attention of healthcare providers who - through completing the duties of their jobs - act as substitute caregivers [36]. These abnormal illness behaviors may extend into adolescence and adulthood. In this way, abnormal illness behaviors may affect the next generation either indirectly - if children model their own behavior after the parent with a history of FD - or directly if the parent abuses their child by forcing them to assume the patient role [18, 24].

\section{Intergenerational Transfer}

It is well established that adults who experienced abuse or neglect as children are more likely to become abusers themselves [37-39]. Therefore, individuals who develop FD in childhood to cope with abuse or neglect may be more likely to become abusers as adults. Through this process of the abused becoming abusers, the offspring of adults who coped with childhood abuse through FD may be at higher risk of becoming victims of FD imposed on another (also called Munchausen syndrome by proxy) [36]. To simplify, the previously FD-afflicted parents may fabricate and impose illness on their children [18, 24]. No studies have formally examined the possibility that FD may run in families through children modeling their own abnormal illness behaviors after their parents.

Further documentation and analysis are required to fully comprehend the psychological aspect of FD in children. There have been large studies on FD imposed on another, where caregivers fabricate medical illness in their children [39]. However, cases of children fabricating their own illnesses have been largely ignored in the literature.

\section{Management}

FD have been considered the most challenging self-inflicted conditions and their management and treatment or specific guidelines have not been consensual so far $[24,40,41]$. Some of the reasons behind this may come from the few cases reported with long follow-up, due to the high frequency of drop out with these patients. This has led to a lack of knowledge on how to deal with the subtleties of the management of these patients.

The treatment strategies for patients with FD in general have been only based on single studies, with more recent emphasis given in the last few years. More recently, the ESDaP [30] published a position paper to compile the knowledge available on self-inflicted skin disorders and proposed a therapeutic approach and management guideline. However, there are few studies on FD specifically in children addressing the subtleties of their management.

In children, the prognosis of FD seems to be better and they may be easier to manage and have a better response to treatment $[42,30]$. However, further studies are required to determine the differences between the adults and children regarding proper approach and suitable strategies.

Regardless of the age of the patient, during the first medical examination, patients with FD do not confess that the condition is self-inflicted, and they do not understand and accept that the behavior is self-inflicted since the mechanism is subconscious, happening in the context of a dissociative state [19]. Thereby, confrontation is not advisable [16, 43-45] as this will 
lead to loss of follow up. However, confrontation can be useful in a non-punitive way [20, 24], but it should not be done as a first step [24] only after a closer doctor-patient relationship has been established. This must include an explanation of the FD namely, by explaining the mismatch between the clinical findings and the diagnostic examinations as well as further followup and treatment strategies. This may work well with children and many of them will be receptive and cooperating [41].

The ideal scenario would be that the patient was first observed in a multidisciplinary team [24, 40, 45], such as in a psychodermatology unit, but if this does not happen, it is important to point out that it is not recommended to automatically refer the patient to a psychiatrist or a psychologist in the first visit. For example, if the first doctor who sees the patient is a dermatologist, that will make the patient feel his doctor does not believe he has a «true» skin disease and, instead, that the patient is responsible for the skin lesions [30] and, as a consequence, the patient will not accept to be seen by a psychiatrist or a psychologist and will not follow up with the same dermatologist [24, 43]. Some authors have reported that this may worsen psychopathology connected with the FD, worsening the denied self-inflicted behavior [29]. Thus, it is recommended that a dermatologist trained in psychodermatology should educate the patient about the underlying psychological basis of the disease and explaining the meaning of dissociative states, basically, that sometimes people can do things under a subconscious state [24].

FD are considered an expression of a psychological stress and a way of calling for help [30, 45]. All the patients with FD have psychiatric comorbidities [24]. There is higher prevalence of eating disorders, traumaand stressor-related disorders, personality disorders (such as borderline disorder) and emotional neglect [42]. In a retrospective study performed with children with FD at the National Institute of Pediatrics in Mexico City, anxiety, depression and personality disorders were the most common comorbidities [27]. For instance, depression can be present before the onset of a FD [30]. Therefore, while approaching a patient with a suspected diagnosis of FD, regardless of his age, it is of utmost importance to perform a psychological assessment and consider possible underlying psychiatric comorbidities [40]. In such cases, the management can eventually become easier since the management of the comorbidities would lead to the improvement of the self-inflicted behavior by itself [44] and by improving the doctor-patient relationship. By utilizing this method, the patient will feel that the focus is on the «psychological stress» that the disease has caused on him instead of the genesis of the disease [45]. Nevertheless, the severity of the psychiatric comorbidity should be thoroughly analyzed as well as the psychosocial and psychiatric risk, such as suicidal thoughts because, in this case, a psychiatric consultation cannot be postponed [40].
When the patient is a child, besides the strategies mentioned above it is also important to pay particular attention to the following. First, it seems that the doctor-patient relationship is especially relevant in children and, if it really works, the child can more easily confess the self-inflicted behavior in first few appointments. A psychoeducation program can be used to achieve these aims. This is important because a recent study highlighted the benefit of psychoeducation in FD [44] and a psychoeducation program can be especially useful with children [16]. Psychoeducation includes the explanation, through an empathetic way, of the symptoms that the patient has, and their distinction from malingering, as well as the possible treatment strategies [44]. If the self-inflicted behavior is on the skin, an explanation of the dermatological examination in layman language adequate to age of the patient and its psychosocial impact can be a good first strategy. Afterwards, this will open the way to explore the psychiatric background directly connected with the development of the self-inflicted behavior, through a nonpunitive confrontation. During this step, it is also relevant to actively involve the patient in looking for what may be under the production of the lesions. We may ask the patient, for instance, to think about what happens around him and what is going on in his mind when the lesions happen. Furthermore, it is important to tell the patient that a treatment exists, but it may need a long way and that all the aspects of the disease are important, including its psychosocial impact as well as the involvement of the patient and his family in all the treatment strategies suggested. It is also important to treat the consequences of the self-inflicted behavior on the body, as well as the psychosocial issues [24]. In the setting of Dermatology, the treatment of the skin lesions with traditional treatment along with the psychoeducational approach together with psychological interventions, ideally in a Psychodermatology multidisciplinary team, have proven to be helpful. The treatment of the skin lesions would make the patient feel that something is being done for him and, even, some authors have suggested occlusion as a good diagnostic and therapeutic tool, since here the physician can show and discuss, in a non-judgmental way, that any additional lesions will appear [45].

Another point that is also quite important in children with FD is to understand the family dynamics and any psychosocial stressors affecting the patient through an interview with the parents [42]. Indeed, problems in the family dynamic were related to the onset ofFD in children [26, 45]. The parents should not be told that the patient has a self-inflicted behavior or that he is the responsible for the lesions, unless they have already expressed it. They should be, however, involved in the treatment strategies as facilitators to improve the family conflicts that may be hypothetically linked with the condition.

Thereafter, together with psychoeducation, a more accurate treatment strategy can be outlined which can be either a psychotropic and/or psychotherapy and may also 
require collaboration of a psychiatrist and/or a psychologist. It is also quite important to distinguish FD in children, where Munchausen syndrome and more severe presentation from FD by proxy, where the symptoms are caused by another person. The latter needs a different approach since the treatment target is the person who is causing the symptoms on the child $[43,46]$.

Psychodermatological evaluation would include a psychological assessment in children with a suspected FD, including the assessment of psychiatric comorbidities, along with the dermatological examination. A dermatologist can do this with training in psychodermatology, which, as previously explained, can facilitate the collaboration of the patient and treatment compliance. The psychological examination should consider the appearance, the speech, the mood, the form and the content of the thoughts, the perception, a cognitive assessment, the insight and the psychosocial risk. This can be complemented by psychiatric questionnaires, such as the hospital anxiety and depression scale [47]. The social and family context should also be explored. Thereafter, the severity of the psychiatric comorbidities can be distinguished as mild, moderate or severe. In the mild form the dermatologist should follow the treatment and psychoeducation, which can help the child dealing with difficult aspects of life, and, as a consequence, this could improve the self-inflicted behavior. In many cases, the child will also confess about self-inflicted behavior. In moderate and severe cases, as well as in the context of a personality disorder [24], the close collaboration of a psychiatrist and a psychologist would be really important and the patient will not refuse it if he feels that his dermatologist did not abandon him [30]. Here, psychotropic drugs are relevant and, depending on the comorbidities, psychotherapy can be started. Finally, together with all the considerations above, the treatment strategy (pharmacology and psychotherapy, detailed below) should be chosen in a personalized and individually tailored approach, especially relevant with in FD [40].

\section{Pharmacology}

There are not specific psychotropic treatments for FD. Furthermore, few studies have addressed the use of psychotropic drugs in children with self-inflicted disorders [42]. We agree that they should be chosen particularly considering the psychiatric comorbidities that the patient may have $[16,40]$. Serotonin reuptake inhibitors have been recommended $[43,45]$ mainly due to the coexistence of depression, anxiety, trauma- and stressor-related disorders. Sertraline was considered a good choice to treat these comorbidities in children with FD with an initial dosage of 12.5-25 mg once daily for children between 6 and 12 years or 25-50 mg for children between 13 and 17 years old, being possible to increase the dose up to $50 \mathrm{mg}$ daily. Other authors have used fluoxetine, $20 \mathrm{mg}$ daily, to treat comorbid depression in adolescents with FD [44]. Anxiolytics, such as, alprazolam, can be transitorily used with benefit in anxiety and some personality disorders but should be used with caution due to addiction potential [48]. It could only be used for a temporary and short-term basis and should be discontinued as soon as possible. Antipsychotics can be useful to improve the impulsive behavior connected with the FD [16, 30, 45, 48]. However psychotropic treatment should be discouraged in this population group due to potentially harmful side effects.

\section{Psychotherapy}

In $\mathrm{FD}$, the psychological mechanism is subconscious and, thereby, cognitive behavior therapy (CBT) specifically to address the factitious condition is not a good choice. CBT could, however, work in the management of the related psychiatric disorders that may be also present, such as in the spectrum of anxiety and depression, helping to improve, thereafter, the FD, but this should obviously take into account the age of the child. Besides, dialectical behavior therapy has proved huge benefit in borderline personality traits [24]. Some authors have advocated a psychodynamic approach directly to the FD, with success [19,30]. Considering the importance of the family context to the child mental health, the usefulness of family therapy has also been encouraged [16]. Besides, the co-existence of more severe comorbidities, such as, body dysmorphic disorder should be ruled out. There is not a single specific psychotherapy that proved to be beneficial [49].

Many cases are, however, chronic, lasting several years, with periods of slight improvement. Sometimes, lack of communication among different health professionals may worsen the prognosis. This is especially important in cases of Munchausen syndrome, which is characterized by a continuous search for medical care. Health professionals who do not understand the disease may help to perpetuate this behavior by prescribing unnecessary medications or performing unnecessary surgical procedures, as we have observed with a patient in our psychodermatology clinic [41] and which is corroborated by other authors [30]. Furthermore, the psychiatric comorbidities and psychosocial context are also important in the prognosis of FD [50].

\section{Conclusions}

Nevertheless, compared to adults, typically children without severe comorbidities and with a shorter duration of the disease have a better prognosis and significant improvement could be anticipated in some months or few years [30, 42, 45]. The course of FD in children and its prognosis and psychiatric comorbidity is highly variable. Finally, understanding the social context (family and school) may also help to find out the trigger of the FD and can be a key in the management and treatment.

Corresponding Author: Mohammad Jafferany, $M D$, FAPA, e-mail: m.jafferany@cmich.edu Authors report no conflict of interest 


\section{Список литературы}

1. Krahn L.E., Li H., O'Connor M.K. Patients who strive to be ill: factitious disorder with physical symptoms. Am J Psychiatry. 2003 Jun, Vol. 160, № 6. P. 1163-1168.

2. A puzzling case of anemia / S. A. Haddad, K. K. Winer, A. Gupta [et al.]. Transfusion. 2002.

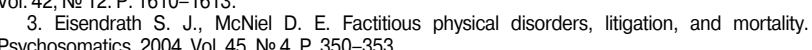
sychosomatics. 2004. Vol. 45, № 4. P. 350-353.

4. Factitious disorders and pathological self-harm in a hospital population: an interdisciplinary chalenge / H. Fliege, G. Scholler, M. Rose [et al.]. Gen Hosp Psychiatry. 2002. Vol. 24, № 3. P. 164-171.
5. Yates G. P., Feldman M. D. Factitious disorder: A systematic review of 455 cases in the profes5. Yates G. P., Feldman M. D. Factitious disorder: A system
sional literature. Gen Hosp Psychiatry. 2016. Vol. 4. P. 20-28.

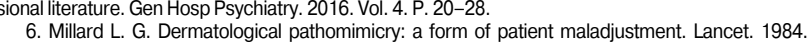
6. Millard L. G. Dermato
Vol. 2. № 8409. P. $969-971$.

7. Cumming S. Deliberate self-harm: have we scratched the surface? / S. Cumming, T. Covic, E. Murrell. Behav Chang. 2006. Vol. 23, № 3. P. 186-199.

8. Autodestructive syndromes / R. D. Kocalevent, M. Rose, M. Walter [et al.]. Psychother Psychosom. 2005. Vol. 74, № 4. P. 202-211.

9. Van Moffaert M. The spectrum of dermatological self-mutilation and self-destruction including dermatitis artefacta and neurotic excoriations / In Koo J. Y.M., Lee C. S., editors. Psychocutaneous

10 , N-inflicted Skin Disecker, 203. P. 69 -89.

10. Self-inticted Skin Diseases. ARe Nospective Analysis of 57 Patients with Dermatitis Artefacta Seen in a Dermatology Department / K. N1.
Venereol. 2005. Vol. 85, № 6. P. 202-211.

11. Frequency of ICD-10 f. 202-21tious disorder: survey of senior hospital consultants and physicians in private practice / H. Fliege, A. Grimm, A. Eckhardt-Henn [et al.]. Psychosomatics. 2007. Vol. 48, № 1. P. $60-64$.

12. Self-inflicted Lesions in Dermatology: Terminology and Classification / U. Gieler, S. G. Consoli, L. T. Dennis [et al.]. A Position Paper from the European Society for Dermatology and Psychiatry (ESDaP). Acta Derm Venereol. 2013. Vol. 20. P. 4-12.

13. Psychiatric morbidity in dermatological outpatients: an issue to be recognized / A. Picardi, D. Abeni, S. F. Melchi [et al.]. Br J Dermatol. 2000. Vol. 143, № 5. P. 983-991.

U. Stangier, Z Hautkr. 1987. Vol. 62, № 11. P. 882-890. 15. The knowledge, awareness, and practice patterns of dermatologists toward psychocutaneous 2010. Vol. 49, № 7. P. 784-789.

16. Jaghab K. Skodnek K. B., Padder Stangier T. A. Munchausen's Syndrome and Other Factitious Disorders in Children: Case Series and Literature Review. Psychiatry (Edgmont). 2006. Vol. 3, № 3. P. 46-55.

17. Case report «Munchausen syndrome by proxy» presenting as battered child syndrome: a report of two cases 7. P. 679-683.

18. Bass C., Glaser D. Early recognition and management of fabricated or induced illness in children. Lancet. 2014. Vol. 383, № 9926. P. 1412-1421.

19. Harth W., Taube K.L., Gieler U. Facticious disorders in dermatology. J Dtsch Dermatol Ges. 2010. Vol. 8, № 5. P. 361-372.

20. Sambhi R., Lepping P. Psychiatric treatments in dermatology: an update. Clin Exp Dermatol. 2010. Vol. 35, № 2. P. $120-125$.

21. Boyd A.S., Ritchie C., Likhari S. Munchausen syndrome and Munchausen syndrome by proxy dermatology. J Am Acad Dermatol. 2014. Vol. 71, № 2. P. 376-381.

22. Yates G., Bass C. The perpetrators of medical child abuse (Munchausen Syndrome by Proxy) -A systematic review of 796 cases Psychiatric treatments in dermatology: an update. Child Abuse Negl. 2017. Vol. 72. P. 45-53.

23. Clinical management in Psychodermatology / Harth W, Gieler U, Kusnir B, Tausk FA. Editors: erlin Heidelberg. Springer-Vrlag, 2009. P. 12-18.

24. Bass C., Halligan P. Factitious disorders and malingering: Challenges for clinical assessment and management. Lancet. 2014. Vol. 383, № 9926. P. 1422-1432.

25. Millard J, Millard L. Factitious skin disorder (dermatitis artefacta) / In Bewley A, Taylor R. E., Reichenberg J. [et al.] Pract Psychodermatology. West Sussex. Willey Blackwell, 2014. P. 142-49. 26. Pichardo A. R., Bravo B. G. Dermatitis artefacta: a review. Actas Dermo-Sifiliográficas (English Ed). 2013. Vol. 104, № 10. P. 854-866.

27. Dermatitis artefacta in pediatric patients: experience at the national institute of pediatrics /
M. Saez-de-Ocariz, L. Orozco-Covarrubias, I. Mora-Magana [etal.]. Pediatr Dermatol. 2004. Vol. 21, №

3. P. 205-211.

28. Artefactual skin lesions in children and adolescents: review of the literature and two cases of fac-

titious purpura / H. C. Ring, I. M. Miller, E. Benfeldt [et al.]. Int J Dermatol. 2015. Vol. 54, № 1. P. $27-32$.

29. Libow J. A. Child and adolescentillness falsification. Pediatrics. 2000. Vol. 105, № 2. P. 336-342. 30. Self-inflicted Lesions in Dermatology: A management and therapeutic approach??? / L. Tomas-
Aragones, S. M. Consoli, S. G. Consoli [et al.]. A Position Paper from the European Society for Aragones, S. M. Consoli, S. G. Consoli [et al.]. A Position Paper from the European Society for
Dermatology and Psychiatry (ESDaP). Acta Derm Venereol. 2017. Vol. 97, № 2. P. 159-172. Dermatology and Psychiatry (ESDaP). Acta Derm Venereol. 2017. Vol. 97, № 2. P. 159-172.
31. Jafferany M., Bhattacharya G. Psychogenic purpura (Gardner-Diamond Syndrome). Care Companion CNS Disord. 2015. Vol. 17, № 1. 14br01697. doi: 10.4088/PCC. 14br01697.

32. Dermatitis artefacta in a patient affected by impulse control disorder: case report / C. Miller C. Potenza, E. Bernardini, A. Mambrin [et al.]. Acta Dermatovenerol Croat. 2011. Vol. 19, № 1. P. $28-30$ 33. Gordon D. K., Sansone R. A. A relationship between factitious disorder and borderline personality disorder. Innov Clin Neurosci. 2013. Vol. 10, № 11-12. P. 11-13.

34. Nock M. K. Self-injury. Annul Rev Clin Psychol. 2010. Vol. 6. P. 339-363.

35. Lawlor A., Kirakowski J. When the lie is the truth: Grounded theory analysis of an online support group for factitious disorder. Psychiatry Res. 2014. Vol. 218. № 1-2. P. 209-218.

36. Kozlowska K. Abnormal illness behaviours: A developmental perspective. Lancet. 2014 ol. 383. № 9926. P. 1368-1369,

37. Romero-Martinez A., Figueiredo B., Moya-Albiol L. Childhood history of abuse and child abuse potential: The role of parent's gender and timing of childhood abuse. Child Abus Negl. 2014. Vol. 38. № 3. P. $510-516$.

38. Plummer M., Cossins A. The cycle of abuse: When victims become offenders. Trauma, Violence, Abuse. 2016. doi: 1524838016659487. [Epub ahead of print]

39. Yates G., Bass C. The perpetrators of medical child abuse (Munchausen Syndrome by Proxy):

systematic review of 796 cases. Child Abuse Negl. 2017. Vol. 72. P. 45-53.

40. Eastwood S., Bisson J. I. Management of factitious disorders: a systematic review. Psychother

Psychosom. 2008. Vol. 77. № 4. P. 209-218.

41. Ferreira B. R., Reis J. P., Figueiredo A. "Secret» Self-Inflicted Skin Lesions: A Challenge Dermatology. Acta Med Port. 2017. Vol. 30. № 2. P. 155-6.

42. Dermatitis Artefacta in Childhood: A Retrospective Analysis of 44 Patients, 1976-2006 / S. Alcántara Luna Ferreira, B. García Bravo, A. Pichardo Rodríguez, F. Martínez Camacho. Pediatric

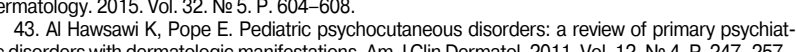
ric disorders with dermatologic manifestations. Am J Clin Dermatol. 2011. Vol. 12. № 4. P. 247-257.
44. Bolat N., Yal in . Factitious Disorder Presenting with Stuttering in Two Adolescents: The 44. Bolat N., Yal in . Factitious Disorder Presenting with Stuttering in Two
mportance of Psychoeducation. Noro Psikiyatr Ars. 2017. Vol. 54. № 1. P. 87-89.

45. Mohandas P.., Bewley A., Taylor R. Dermatitis artefacta and artefactual skin disease: the need
4. The 45. Mohandas P., Bewley A., Taylor R. Dermatitis artefacta and artefactual skin disease: the need
for a psychodermatology multidisciplinary team to treat a difficult condition. Br J Dermatol. 2013. for a psychodermatology muth
Vol. 169. № 3. P. 600-606.

46. Factitious disorders and Munchausen syndrome: the tip of the iceberg / P. Ferrara, O. Vitelli, G. Bottaro [et al.]. J Child Health Care. 2013. Vol. 17. № 4. P. 336-374

47. Validation study of a Portuguese version of the Hospital Anxiety and Depression Scale J8 PaisRibeiro, I. Silva, T. Ferreira [etal.]. Psychology, Health \& Medicine. 2007. Vol. 12. № 2. P. 225-237. 48. Schatzberg A. F., DeBattista C. Manual de Psicofarmacologia Clínica. So Paulo: Artmed. 2017.
49. Müller S. Body integrity identity disorder (BIID)-is the amputation of healthy limbs ethically jus49. Müller S. Body integrity identity disorder (BID
tified? Am J Bioeth. 2009. Vol. 9. № 1.P. 36-43.

50. Pathomimie de l'enfant: propos d'une observation / N. Dini, H. Ourai, M. Kmari [et al.]. The

Pan African Medical Journal. 2013. Vol. 14. P. 23-25.

\section{References}

1. Krahn LE, LiH, O'Connor MK. Patients who strive to be ill: factitious disorder with physical symptoms. Am J Psychiatry. 2003;160(6):1163-8.

2. Haddad SA, Winer KK, Gupta A, Chakrabarti S, Noel P, Klein HG. A puzzling case of anemia. Transfusion. 2002;42(12):1610-3.

3. Eisendrath SJ, McNiel DE. Factitious physical disorders, litigation, and mortality. Psychosomatics. 004;45(4):350-3.

4. Fliege $\mathrm{H}$, Scholler G, Rose M, Willenberg $H$, Klapp BF. Factitious disorders and pathological selfarm in a hospital population: an interdisciplinary challenge. Gen Hosp Psychiatry. 2002;24(3):164-71. 5. Yates GP, Feldman MD. Factitious disorder: A systematic review of 455 cases in the professional terature. Gen Hosp Psychiatry. 2016;41:20-8.

6. Millard LG. Dermatological pathomimicry: a form of patient maladjustment. Lancet. 984;2(8409):969-71.

7. Cumming S, Covic T, Murrell E. Deliberate self-harm: have we scratched the surface? Behav Chang. 2006;23(3): 186-99.

8. Kocalevent R-D, Fliege H, Rose M, Walter M, Danzer G, Klapp BF. Autodestructive syndromes. sychother Psychosom. 2005;74(4):202-11.

9. Van Moffaert M. The spectrum of dermatological self-mutilation and self-destruction including dermatitis artefacta and neurotic excoriations. In Koo JYM, Lee CS, editors. Psychocutaneous Medicine; New York; Marcel Decker; 2003. P. 169-89.

10. Nielsen K, Jeppensen M, Simmelsgaard L, et al. Self-inflicted Skin Diseases. A Retrospective Analysis of 57 Patients with Dermatitis Artefacta Seen in a Dermatology Department. Acta Derm Venereol. 2005;85(6):202-211.

11. Fliege H, Grimm A, Eckhardt-Henn A, et al. Frequency of ICD-10 factitious disorder: survey senior hospital consultants and physicians in private practice. Psychosomatics. 2007;48(1):60-4. 12. Gieler U, Consoli SG, Dennis LT, et al. Self-inflicted Lesions in Dermatology: Terminology and
Classification - A Position Paper from the European Society for Dermatology and Psychiatry (ESDaP).

2013;20:4-12.

13. Picardi A, Abeni D, Melchi CF, et al. Psychiatric morbidity in dermatological outpatients: an issue to be recognized. Br J Dermatol. 2000;143(5):983-91.

14. Gieler U, Effendy I, Stangier U. Cutaneous artefacts - possibilities for treatment and their limZ Z Hautkr. 1987;62(11):882-90.

15. Jafferany M, Stoep A Vander, Dumitrescu A, et al. The knowledge, awareness, and practice patterns of dermatologists toward psychocutaneous disorders: results of a survey study. 2010;49(7):784-89.

16. Jaghab K, Skodnek KB, Padder TA. Munchausen's Syndrome and Other Factitious Disorders Children: Case Series and Literature Review. Psychiatry (Edgmont). 2006;3(3):46-55

17. Sugandhan S, Gupta S, Khandpur S, et al. Case report "Munchausen syndrome by proxy" resenting as battered child syndrome: a report of two cases. Int J Dermatol. 2010;49(6):679-83.

18. Bass C, Glaser D. Early recognition and management of fabricated or induced illness in chilen. Lancet. 2014;383(9926): 1412-2

19. Harth W, Taube K-M, Gieler U. Facticious disorders in dermatology. J Dtsch Dermatol Ges. 2010;8(5):361-72.

20. Sambhi R, Lepping P. Psychiatric treatments in dermatology: an update. Clin Exp Dermatol. 10;35(2):120-5

21. Boyd AS, Ritchie C, Likhari S. Munchausen syndrome and Munchausen syndrome by proxy dermatology. J Am Acad Dermatol. 2014;71(2):376-81.

22. Yates G, Bass C. The perpetrators of medical child abuse (Munchausen Syndrome by Proxy)-A systematic review of 796 cases. Child Abuse Negl. 2017;72:45-53.

23. Harth W, Gieler U, Kusnir B, Tausk FA. Editors: Clinical management in Psychodermatology. erlin Heidelberg. Springer-Vrlag, 2009. P. 12-18.

24. Bass C, Halligan P. Factitious disorders and malingering: Challenges for clinical assessment d management. Lancet. 2014;383(9926):1422-32.

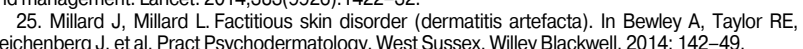
Reichenberg J, et al. Pract Psychodermatology. West Sussex. Willey Blackwell. 2014; 142-49.
26. Pichardo AR, Bravo BG. Dermatitis artefacta: a review. Actas Dermo-Sifiliográficas (Englis 26. Pichardo AR, Bravo

27. Saez-de-Ocariz M, Orozco-Covarrubias L, Mora-Magana I, et al. Dermatitis artefacta in pediatric patients: experience at the national institute of pediatrics. Pediatr Dermatol. 2004;21(3):205-11. 28. Ring HC, Miller IM, Benfeldt E, et al. Artefactual skin lesions in children and adolescents: review of the literature and two cases of factitious purpura. Int J Dermatol. 2015;54(1):27-32.

29. Libow JA. Child and adolescent illness falsification. Pediatrics. 2000;105(2):336-42.
30. Tomas-Aragones L, Consoli SM, Consoli SG, et al. Self-inflicted lesions in dermatology: A man30. Tomas-Aragones L, Consoli SM, Consoli SG, et al. Self-inflicted lesions in dermatology: A man-
agement and therapeutic approach??? A position paper from the European Society for Dermatology agement and therapeutic approach??? A position paper f

31. Jafferany, M, Bhattacharya G. Psychogenic purpura (Gardner-Diamond Syndrome) Prim Care 31. Jafferany, M, Bhattacharya G. Psychogenic purpura (Gardner-Diamond Syndrome) Prim
Pan

32. Potenza C, Bernardini N, Mambrin A, et al. Dermatitis artefacta in a patient affected by impulse 32. Potenza C, Bernardini N, Mambrin A, etal. Dermatitis artefacta in a patiente

33. Gordon DK, Sansone RA. A relationship between factitious disorder and borderline personality sorder. Innov Clin Neurosci. 2013:10(11-12):11-3.

34. Nock MK. Self-injury. Annu Rev Clin Psychol. 2010;6:339-63.

35. Lawlor A, Kirakowski J. When the lie is the truth: Grounded theory analysis of an online support group for factitious disorder. Psychiatry Res. 2014;218(1-2):209-218. doi:10.1016/j.psychres.2014.03.034

36. Kozlowska K. Abnorme

37. 37. Romero-Martinez A, Figueiredo B, Moya-Albiol L. Childhood history of abuse and child abuse

516. 38. Plummer M, Cossins A. The cycle of abuse: When victims beco
buse. 2016 Jul 19. doi: 1524838016659487 . [Epub ahead of print].

39. Yates G, Bass C. The perpetrators of medical child abuse (Munchausen Syndrome by Proxy): 39. Yates G, Bass C. The perpetrators of medical child abuse (Munch
systematic review of 796 cases. Child Abuse Negl. 2017;72:45-53.

systematic review of 796 cases. Child Abuse Negl. 2017;72:45-53.
40. Eastwood S, Bisson Jl. Management of factitious disorders: a systematic review. Psychother Psychosom. 2008;77(4):209-18.

41. Ferreira BR, Reis JP, Figueiredo A. "Secret" Self-Inflicted Skin Lesions: A Challenge Dermatology. Acta Med Port. 2017;30(2):155.

42. Alcántara Luna S, García Bravo B, Pichardo Rodríguez A, Martínez Camacho F. Dermatitis Artefacta in Childhood: A Retrospective Analysis of 44 Patients, 1976-2006. Pediatric dermatology. 2015;32(5):604-608.

43. Al Hawsawi K, Pope E. Pediatric psychocutaneous disorders: a review of primary psychiatric disders with dermatologic manifestations. Am J Clin Dermatol. 2011;12(4):247-57.

44. Bolat N, Yal in . Factitious Disorder Presenting with Stuttering in Two Adolescents: The mportance of Psychoeducation. Noro Psikiyatr Ars. 2017;54(1):87-89.

45. Mohandas P, Bewley A, Taylor R. Dermatitis artefacta and artefactual skin disease: the need for a psychodermatology multidisciplinary team to treat a difficult condition. $\mathrm{Br} J$ Dermatol. 2013;169(3):600-6.

46. Ferrara P, Vitelli O, Bottaro G, Gatto A, Liberatore P, Binetti P, Stabile A. Factitious disorders and Munchausen syndrome: the tip of the iceberg. J Child Health Care. 2013;17(4):366-74

47. Pais-Ribeiro J, Silva I, Ferreira T, Martins A, Meneses R, Baltar M. Validation study 2007;12(2):225-237.

48. Schatzberg AF, DeBattista C. Manual de Psicofarmacologia Clínica. So Paulo: Artmed; 2017. 49. Müller S. Body integrity identity disorder (BIID) -is the amputation of healthy limbs ethically jusified? Am J Bioeth. 2009;9(1):36-43.

50. Abilkassem R, Dini N, Ourai H, Kmari M, Agadr A. Pathomimie de l'enfant: propos d'une observation. The Pan African Medical Journal. 2013;14:23. 


\title{
СИМУЛЯТИВНЫЕ РАССТРОЙСТВА У ДЕТЕЙ: КЛИНИКА И ТЕРАПИЯ
}

\section{М. Джафферани ${ }^{1}$, А. Кобусевич², Б.Р. Феррейра ${ }^{3}$, С. Гаран ${ }^{4}$, А. Гаврилюк ${ }^{5,6}$}

${ }^{1}$ Центральный университет Мичигана, Медицинский колледж, г. Сагино, штат Мичиган, Соединенные Штаты Америки

2 Лодзинский университет, г. Лодзь, Польша

${ }^{3}$ Университет Коимбра, г. Коимбра, Португалия

${ }^{4}$ Эстебель Эстетик Клиника, г. Стамбул, Турция

${ }^{5}$ Харьковский национальный медицинский университет, г. Харьков, Украина

${ }^{6}$ Гу «Институт дерматологии и венерологии НАМН Украины», г. Харьков, Украина

\section{Резюме}

Существует значительный недостаток осведомленности врачей-дерматологов о детях и подростках, умышленно вызывающих дерматологические симптомы, и эта уникальная группа остается недооцененной.

Цель: данный обзор литературы является материалом для дерматологов о патогенезе, симптоматологии и способах лечения симулятивных расстройств.

Материалы и методы: проводился поиск статей, содержащих слова «симулятивные расстройства» и «артефициальный дерматит» в базе Medline за последние два десятилетия.

Результаты. Дети с симулятивными расстройствами страдают и другими психическими расстройствами, особенно депрессией и пограничными расстройствами личности. Распространенность колеблется в пределах от 0,5 до 2\%. Большинство детей и подростков, у которых отмечается самоповреждающее поведение, не намерены совершать самоубийство, они используют такое поведение как обращение за помощью или невербальную форму общения.

Выводы. С пациентами не следует заострять психологический конфликт, лежащий в основе этого состояния, достаточно неосуждающего, эмпатического подхода для хорошего терапевтического эффекта и установления доверительных отношений. Высокая настороженность со стороны медицинского персонала является ключом к диагностике данных расстройств. Наряду с дерматологической помощью применение психофармакологических препаратов и психотерапевтических методов повышает эффективность терапии в данной группе населения.

Ключевые слова: психокожные расстройства, симулятивные расстройства, психодерматология.

\section{СИМУЛЯТИВНІ РОЗЛАДИ У ДІТЕЙ: КЛІНІКА І ТЕРАПІЯ}

\author{
М. Джафферані ${ }^{1}$, О. Кобусевич², Б.Р. Феррейра ${ }^{3}$, С. Гаран ${ }^{4}$, О. Гаврилюк ${ }^{5,6}$ \\ ${ }^{1}$ Центральний університет Мічігану, Медичний коледж, м. Сагіно, штат Мічіган, Сполучені Штати Америки \\ 2 Лодзинський університет, м. Лодзь, Польща \\ ${ }^{3}$ Університет Коімбра, м. Коімбра, Португалія \\ ${ }^{4}$ Естебель Естетик Клініка, м. Стамбул, Туреччина \\ ${ }^{5}$ Харківський національний медичний університет, м. Харків, Україна \\ ${ }^{6}$ ду «Інститут дерматології та венерології НАМН України», м. Харків, Україна
}

\section{Резюме}

Існує значний недолік обізнаності лікарів-дерматологів про дітей і підлітків, які навмисно спричинюють дерматологічні симптоми, ця унікальна група залишається недооціненою.

Мета: даний огляд літератури є матеріалом для дерматологів про патогенез, симптоматологію та способи лікування симулятивних розладів.

Матеріали та методи: проводився пошук статей, що містять слова «симулятивні розлади» та «артефіціальний дерматит», в базі Medline за останні два десятиріччя.

Результати. Діти з симулятивними розладами страждають ще й на інші психічні розлади, особливо на депресію та межові розлади особистості. Поширеність коливається в межах від 0,5 до 2\%. Більшість дітей і підлітків, які мають самоушкоджуючу поведінку, не мають наміру здійснювати самогубство, вони використовують таку поведінку як звернення по допомогу або невербальну форму спілкування.

Висновки. 3 пацієнтами не слід загострювати психологічний конфлікт, що лежить в основі цього стану, досить неосудливого, емпатичного підходу для хорошого терапевтичного ефекту та встановлення довірливого ставлення. Висока настороженість з боку медичного персоналу є ключем до діагностики даних розладів. Поряд з дерматологічною допомогою застосування психофармакологічних препаратів і психотерапевтичних методів підвищують ефективність терапії в цій групі населення. Ключові слова: психошкірні розлади, симулятивні розлади, психодерматологія.

\section{Відомості про авторів:}

Mohammad Jafferany - MD, FAPA, clinical associate professor of psychiatry and psychodermatology of the Department of Psychiatry, Central Michigan University, College of Medicine, Saginaw, USA; e-mail: m.jafferany@cmich.edu.

ORCID ID: https://orcid.org/0000-0001-6385-9064

Aleksandra Kobusiewicz - MD, University of Lodz, Lodz, Poland.

Barbara R. Ferreira - MD, University of Coimbra, Coimbra, Portugal.

Serpil Garan - MD, Estebel Aesthetic Clinic, Istanbul, Turkey.

Oleksandra Havryliuk - PhD, Kharkiv National Medical University; State Establishment «Institute of Dermatology and Venereology of NAMS of Ukraine".

ORCID ID: https://orcid.org/0000-0003-0596-732X 